\title{
Penerapan Metode Fuzzy Tsukamoto Dalam Pemilihan Siswa Teladan di Sekolah
}

\author{
Fatehson Dendah Ragestu', Alexander J.P. Sibarani2 ${ }^{*}$ \\ 1,2Program Studi Teknik Informatika, Fakultas Teknologi Informasi, Universitas Budi Luhur, DKI Jakarta \\ Email: ${ }^{1}$ fatehson83@gmail.com, ${ }^{2 *}$ alexander.sibarani@budiluhur.ac.id
}

(Naskah masuk: 11 Feb 2020, direvisi: 30 Mar 2020, diterima: 31 Mar 2020)

\begin{abstract}
Abstrak
Penelitian ini dilakukan pada Sekolah Menengah Pertama (SMP) Mazroatul Ulum di Tangerang. Sekolah ini berusaha untuk meningkatkan mutu dan daya saing dari siswa-siswi agar dapat bersaing dengan sekolah lainnya. Salah satu cara yang diambil adalah dengan menerapkan pemilihan murid teladan berdasarkan penilaian yang diperoleh. Proses untuk menentukan predikat siswa teladan di SMP Mazro'atul Ulum saat ini dengan mempertimbangkan 4 kriteria yaitu data rata-rata rapor, total absensi berdasarkan alpha, nilai kepribadian, dan nilai ekstrakurikuler. Sebelumnya, sekolah ini belum memiliki aturan yang valid mengenai kriteria terhadap pemilihan siswa teladan. Untuk mengatasi masalah tersebut, dikembangkan Sistem Pendukung Keputusan (SPK) dengan metode Fuzzy Tsukamoto. Metode tersebut merupakan pilihan yang tepat dalam menangani masalah pengambilan sebuah keputusan yang menggunakan beberapa kriteria hingga menghasilkan dua keputusan yaitu teladan dan tidak teladan. Jika nilai probabilitas siswa lebih besar sama dengan 70 maka masuk ke rekomendasi teladan dan jika di bawah 70 maka tidak teladan. Dalam pengujian yang dilakukan pada data siswa kelas 7, 8, dan 9 pada tahun ajaran 2018/2019, bahwa sistem ini dapat menentukan siswa yang berhak mendapatkan predikat teladan dan memberikan penilaian dari hasil keputusan dengan tepat dan efisien.
\end{abstract}

Kata Kunci: Siswa Teladan, Fuzzy Inference System, Metode Tsukamoto

\section{The Application of Fuzzy Tsukamoto Method in the Selection of Exemplary Students at School}

\begin{abstract}
This research was conducted at the Mazroatul Ulum Junior High School in Tangerang. This school strives to improve the quality and competitiveness of students in order to compete with other schools. One of the methods taken is by applying the selection of exemplary students based on the assessments obtained. The process to determine the predicate of exemplary students in the Mazro'atul Ulum Junior High School is currently taking into account 4 criteria, namely the average of report card data, total of absences based on alpha, personality values, and extracurricular values. Previously, this school did not have valid rules regarding criteria for the selection of exemplary students. To overcome these problems, a Decision Support System (DSS) was developed using the Fuzzy Tsukamoto method. The method is the right choice in dealing with the problem of making a decision that uses several criteria to produce two decisions namely role model and not role model. If the student's probability value is greater than 70 then enter into an exemplary recommendation and if under 70 then it is not exemplary. In testing conducted on data of students in grades 7, 8, and 9 in the 2018/2019 academic year, this system can determine students who are entitled to an exemplary title and provide an assessment of the outcome of the decision correctly and efficiently.
\end{abstract}

Keywords: Exemplary Student, Fuzzy Inference System, Tsukamoto Method 


\section{PENDAHULUAN}

Siswa teladan adalah siswa yang memiliki prestasi dan memiliki nilai yang tinggi dari segi akademik maupun nonakademik. Setiap akhir semester, SMP Mazroatul Ulum mengeluarkan nilai rapor yang berisi nilai dari masing-masing mata pelajaran, nilai ahklak siswa berdasarkan aspek kepribadian, nilai keaktifan siswa yang didapat dari data siswa yang mengikuti kegiatan ekstrakurikuler, dan nilai absensi atau kehadiran.

Proses untuk menentukan predikat siswa teladan di SMP Mazro'atul Ulum saat ini dengan mempertimbangkan data nilai siswa yaitu nilai rata-rata rapor, total absensi berdasarkan alpha, nilai kepribadian, dan nilai ekstrakurikuler. Pertamatama para guru mata pelajaran dan guru ekstrakurikuler memberikan hasil nilai akhir semester siswa kepada guru wali kelas, lalu guru wali kelas meratakan total nilai rapor, absensi, kepribadian, dan ekstrakurikuler. Kemudian wali kelas meminta izin kepada kepala sekolah untuk mengadakan musyawarah dengan para guru untuk menentukan siswa yang layak mendapatkan predikat siswa teladan, dimana setelah itu kepala sekolah menyetujui siswa yang layak mendapatkan predikat siswa teladan dari hasil musyawarah. Di SMP Mazro'atul Ulum pendapat para guru tentang menentukan predikat siswa teladan berbeda, ada yang berpendapat bahwa nilai ekstrakurikuler dan kepribadian tidak terlalu diperhatikan. Misalnya, terdapat siswa yang dikategorikan siswa teladan hanya dengan memperhatikan dua kategori yaitu memiliki nilai rata-rata rapor yang tinggi dan alpha yang dikategorikan sedikit. Hal ini berarti para guru hanya memperhatikan dari nilai rata-rata rapor dan absensi saja.

Untuk mengatasi masalah tersebut, perlu dikembangkan Sistem Pendukung Keputusan (SPK) yang dapat membantu pihak sekolah dalam menentukan siswa yang berhak mendapatkan penilaian siswa teladan. Namun sistem pemilihan siswa teladan yang berdasarkan nilai akademik ini membuat siswa kurang berkembang dalam persaingan non akademik. Oleh karena itu dilakukan perubahan dengan cara memasukkan aspek-aspek non akademik seperti akhlak dan ekstrakurikuler dalam pemilihan siswa teladan. Semua penilaian tersebut membutuhkan perhitungan yang adil dan tepat serta lebih efektif. Metode Fuzzy Tsukamoto merupakan pilihan yang tepat dalam menangani masalah pengambilan sebuah keputusan yang menggunakan beberapa kriteria. Dengan metode ini, semua kriteria itu memiliki nilai yang sama sehingga tidak memiliki bobot yang berbeda seperti metode lain. Jadi dengan menggunakan metode Fuzzy Tsukamoto merupakan pilihan yang tepat karena mempertimbangkan semua kriteria yang akan diperhitungkan.

Terdapat beberapa penelitian yang digunakan sebagai referensi pada penelitian ini. Seperti pada penelitian Saifulloh dkk. (2016), tema penelitian mengembangkan sebuah sistem pendukung keputusan yang mampu membantu pihak kredit dalam mengambil sebuah keputusan. Sistem pendukung keputusan ini menggunakan penerapan metode Logika Fuzzy. Penelitian ini nantinya menghasilkan suatu prototype sistem dimana fungsinya menghasilkan keputusan kelayakan pemberian kredit dan alternatif keputusan berdasarkan nominal pengajuan [1]. Pada penelitian Aditya Anggun dkk. (2016), peneliti membangun sebuah sistem rekomendasi pembelian smartphone dengan memanfaatkan sistem pendukung keputusan yang dikembangkan. Metode yang digunakan adalah Fuzzy Tsukamoto. Sistem ini menghasilkan keputusan untuk kelayakan pembelian smartphone berdasarkan kriteria body dimensi, memory internal, RAM, kamera depan, kamera belakang, baterai, dan harga [2]. Sementara pada penelitian yang dilakukan Erlangga dkk. (2018), Metode Fuzzy Tsukamoto digunakan untuk membangun sebuah sistem pendukung keputusan penentuan penerimaan penghargaan atas kinerja dosen. Penelitian ini menggunakan 5 kriteria yang sudah ditentukan yaitu Lama Kerja, Absensi, Indeks Kinerja, Pengabdian dan Penelitian. Hasil dari uji coba diperoleh data dosen yang layak mendapatkan award [3].

\section{METODOLOGI PENELITIAN}

\section{A. Definisi}

Fuzzy secara bahasa diartikan sebagai kabur atau samarsamar. Dalam fuzzy dikenal derajat keanggotaan yang memiliki rentang nilai 0 hingga 1 . Berbeda dengan himpunan yang memiliki nilai 0 atau 1. Sedangkan logika fuzzy adalah suatu cara yang tepat untuk memetakan suatu ruang input ke dalam suatu ruang output, mempunyai nilai kontinyu, fuzzy dinyatakan dalam derajat dari suatu keanggotaan dan derajat dari kebenaran. Oleh sebab itu sesuatu dapat dikatakan sebagian benar dan sebagian salah pada waktu yang sama [4].

Logika fuzzy adalah cabang dari sistem kecerdasan buatan (Artificial Intelligence) yang menstimulasi kemampuan manusia dalam berfikir ke dalam bentuk algoritma yang kemudian dijalankan oleh mesin. Algoritma ini digunakan dalam berbagai aplikasi pemrosesan data yang tidak dapat direpresentasikan dalam bentuk biner. Logika fuzzy menginterpretasikan statemen yang samar menjadi sebuah pengertian yang logis.

Sistem inferensi metode fuzzy Tsukamoto membentuk sebuah rules based atau basis aturan dalam bentuk "sebabakibat" atau "if-then". Langkah pertama dalam perhitungan metode Fuzzy Tsukamoto adalah membuat suatu aturan atau rule fuzzy. Langkah selanjutnya, dihitung derajat keanggotaan sesuai dengan aturan yang telah dibuat. Setelah diketahui nilai derajat keanggotaan dari masing-masing aturan fuzzy, dapat ditentukan nilai alpha predikat dengan cara menggunakan operasi himpunan fuzzy [5].

Fungsi linier turun yaitu himpunan fuzzy dimulai dari nilai wilayah dengan derajat keanggotaan tertinggi pada sisi kiri, kemudian bergerak menurun ke nilai domain yang memiliki derajat keanggotaan lebih rendah. Suatu fungsi derajat keanggotaan fuzzy disebut fungsi linier turun jika mempunyai 2 parameter, yaitu a, $\mathrm{b} \in \mathrm{R}$, dan dinyatakan dengan aturan [6]:

$$
\mu(x ; a, b)= \begin{cases}1 & ; x<a \\ (b-x) /(b-a) & ; a \leq x \leq b \\ 0 & ; x>b\end{cases}
$$


Kurva fungsi linier turun diperlihatkan oleh Gambar 1 [7].

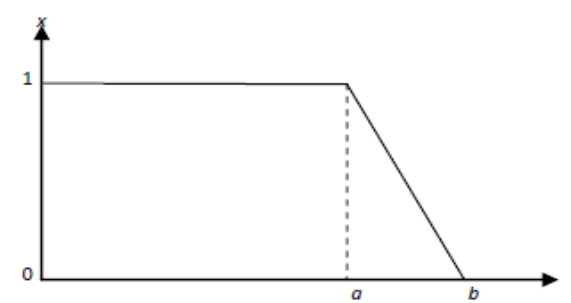

Gambar 1. Kurva Fungsi Linier Turun

Fungsi linier naik yaitu kenaikan himpunan fuzzy dimulai pada nilai wilayah yang memiliki derajat keanggotaan nol bergerak ke kanan menuju nilai wilayah yang memiliki derajat keanggotaan lebih tinggi. Fungsi derajat keanggotaan fuzzy disebut fungsi linier naik jika mempunyai 2 parameter, yaitu $a, b \in R$, dan dinyatakan dengan aturan:

$\mu(x ; a, b)= \begin{cases}0 & ; x \leq a \\ (x-a) /(b-a) & ; a \leq x \leq b \\ 1 & ; x \geq b\end{cases}$

Kurva fungsi linier naik diperlihatkan oleh Gambar 2.

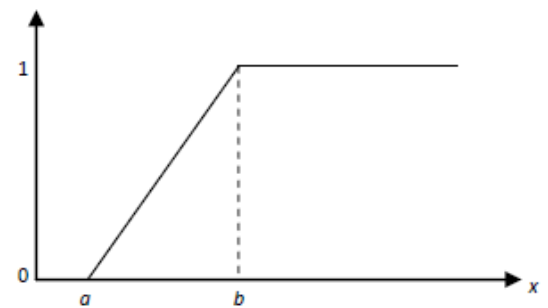

Gambar 2. Kurva Fungsi Linier Naik

Suatu fungsi derajat keanggotaan fuzzy disebut fungsi segitiga jika mempunyai tiga buah parameter, yaitu $p, q, r \in R$ dengan $\mathrm{p}<\mathrm{q}<\mathrm{r}$ dan dinyatakan dengan aturan:

$$
\mu(\mathrm{x}, \mathrm{p}, \mathrm{q}, \mathrm{r})= \begin{cases}(\mathrm{x}-\mathrm{p}) /(\mathrm{q}-\mathrm{p}) & ; \mathrm{p} \leq \mathrm{x} \leq \mathrm{q} \\ (\mathrm{r}-\mathrm{x}) /(\mathrm{r}-\mathrm{q}) & ; \mathrm{q} \leq \mathrm{x} \leq \mathrm{r} \\ 0 & ; \mathrm{x}<\mathrm{p} \text { atau } \mathrm{x}>\mathrm{r}\end{cases}
$$

Kurva fungsi segitiga diperlihatkan oleh Gambar 3.

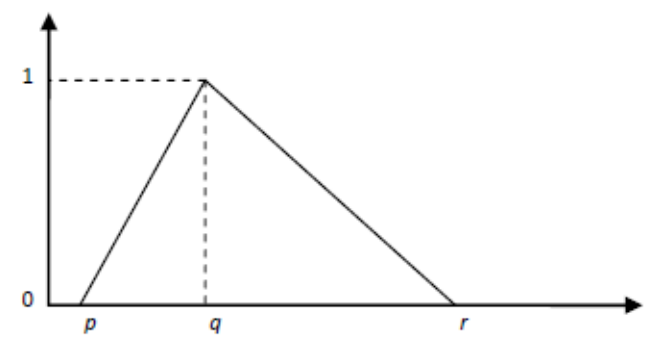

Gambar 1. Kurva Fungsi Segitiga

\section{B. Metode Pengumpulan Data}

Metode ini dilakukan untuk mengumpulkan data dengan mencari referensi, jurnal, buku-buku, skripsi, dan melakukan wawancara untuk mendapatkan data dengan cara tanya jawab secara langsung kepada pihak SMP Mazro'atul Ulum untuk mengetahui permasalahan yang dihadapi dan mendiskusikan aplikasi yang diharapkan dapat memecahkan masalah tersebut.

\section{Metode Membangun Sistem}

Metode ini dilakukan untuk membangun sistem dengan membuat perancangan basis data dan rancangan layar yang akan dibuat dalam sistem. Setelah rancangan selesai, mulailah membuat program yang digunakan. Platform program yang digunakan berbasis desktop. Setelah program selesai, lalu melakukan uji coba terhadap program dan melakukan evaluasi dari hasil uji coba program.

\section{Analisis dan Penyelesaian Masalah}

Proses untuk menentukan predikat siswa teladan di SMP Mazro'atul Ulum saat ini dengan mempertimbangkan data nilai siswa yaitu nilai rata-rata rapor, total absensi berdasarkan alpha, nilai kepribadian, dan nilai ekstrakurikuler. Pertamatama para guru mata pelajaran dan guru ekstrakurikuler memberikan hasil nilai akhir semester siswa kepada guru wali kelas, lalu guru wali kelas meratakan total nilai rapor, absensi, kepribadian, dan ekstrakurikuler. Lalu wali kelas meminta izin kepada kepala sekolah untuk mengadakan musyawarah dengan para guru untuk menentukan siswa yang layak mendapatkan predikat siswa teladan, setelah itu kepala sekolah menyetujui siswa yang layak mendapatkan predikat siswa teladan dari hasil musyawarah. Oleh karena itu diperlukan aplikasi yang dapat membantu dalam memberikan rekomendasi yang tepat untuk menentukan predikat siswa teladan dengan mengimplementasikan metode Fuzzy Tsukamoto.

E. Himpunan Input dan Output Keanggotaan Fuzzy

Rincian himpunan input dalam penentuan rekomendasi predikat siswa teladan disajikan pada Tabel 1 .

Tabel 1. Himpunan Input Fuzzy

\begin{tabular}{lll}
\hline \multicolumn{1}{c}{ Variabel } & \multicolumn{1}{c}{ Himpunan Input } & Domain \\
& Rendah & \\
\hline Nilai rata-rata & Sedang & {$[60-75]$} \\
Rapor & Tinggi & {$[60-100]$} \\
& Baik & {$[0-100]$} \\
\hline Nilai Absensi & Sedang & {$[0-7]$} \\
& Buruk & {$[5-7]$} \\
\hline Nilai & Tidak Baik & {$[40-60]$} \\
Kepribadian & Cukup Baik & {$[40-100]$} \\
& Sangat Baik & {$[60-100]$} \\
\hline Nilai & Tidak Baik & {$[40-60]$} \\
Ekstrakurikuler & Cukup Baik & {$[40-100]$} \\
& Sangat Baik & {$[60-100]$} \\
\hline
\end{tabular}


Rincian himpunan output dalam penentuan rekomendasi predikat siswa teladan disajikan pada Tabel 2 .

Tabel 2. Himpunan Output

\begin{tabular}{lll}
\hline \multicolumn{1}{c}{ Variabel } & \multicolumn{1}{c}{$\begin{array}{c}\text { Himpunan Output } \\
\text { Fuzzy }\end{array}$} & Domain \\
\hline Hasil & Tidak Teladan & {$[0-70]$} \\
Rekomendasi & Teladan & {$[70-100]$} \\
\hline
\end{tabular}

F. Derajat Keanggotaan Fuzzy

i. Derajat Keanggotaan Nilai Rata-rata Rapor

$$
\begin{aligned}
& \mu \operatorname{Rendahl}(\mathrm{x})= \begin{cases}1 & ; \mathrm{x}<60 \\
(75-\mathrm{x}) / 75-60 & ; 60 \leq \mathrm{x} \leq 75 \\
0 & ; \mathrm{x}>75\end{cases} \\
& \mu \operatorname{Sedangl}(\mathrm{x})= \begin{cases}(\mathrm{x}-60) / 75-60 & ; 60 \leq \mathrm{x}<75 \\
(100-\mathrm{x}) / 100-75 & ; 75 \leq \mathrm{x}<100 \\
0 & ; \mathrm{x}<60 \| \mathrm{x}>100\end{cases} \\
& \mu \text { Tinggil }(\mathrm{x})= \begin{cases}1 & ; \mathrm{x}>100 \\
(\mathrm{x}-75) / 100-75 & ; 75 \leq x \leq 100 \\
0 & ; \mathrm{x}>75\end{cases}
\end{aligned}
$$

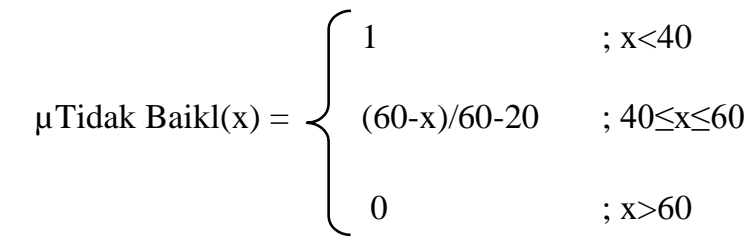

$\mu$ Cukup Baikl $(\mathrm{x})= \begin{cases}(\mathrm{x}-40) / 60-40 & ; 40 \leq \mathrm{x}<60 \\ (100-\mathrm{x}) / 100-60 & ; 60 \leq \mathrm{x}<100 \\ 0 & ; \mathrm{x}<40 \| \mathrm{x}>100\end{cases}$

$\mu$ Sangat Baikl(x) $\begin{cases}1 & ; x>100 \\ (x-60) / 100-60 & ; 60 \leq x \leq 100 \\ 0 & ; x<60\end{cases}$

iv. Derajat Keanggotaan Ekstrakurikuler

(5) $\quad \mu \operatorname{Tidak} \operatorname{Baikl}(\mathrm{x})= \begin{cases}1 & ; \mathrm{x}<40 \\ (60-\mathrm{x}) / 60-20 & ; 40 \leq \mathrm{x} \leq 60 \\ 0 & ; \mathrm{x}>60\end{cases}$

ii. Derajat Keanggotaan Absen

$$
\begin{aligned}
& \mu \operatorname{Baikl}(x)= \begin{cases}1 & ; x<0 \\
(5-x) / 5 & ; 0 \leq x \leq 5 \\
0 & ; x>5\end{cases} \\
& \mu \operatorname{Sedangl}(x)= \begin{cases}(x-0) / 5 & ; 0 \leq x<5 \\
(7-x) / 7-5 & ; 5 \leq x<7 \\
0 & ; x<0 \| x>7\end{cases} \\
& \mu \operatorname{Burukl}(x)= \begin{cases}1 & ; x>7 \\
(x-5) / 7-5 & ; 5 \leq x \leq 7 \\
0 & ; x<5\end{cases}
\end{aligned}
$$

iii. Derajat Keanggotaan Nilai Ekstrakurikuler
(6)

$\mu$ Cukup Baikl $(x)= \begin{cases}(\mathrm{x}-40) / 60-40 & ; 40 \leq \mathrm{x}<60 \\ (100-\mathrm{x}) / 100-60 & ; 60 \leq \mathrm{x}<100 \\ 0 & ; \mathrm{x}<40 \| \mathrm{x}>100\end{cases}$

$\mu$ Sangat Baikl(x) $= \begin{cases}1 & ; x>100 \\ (x-60) / 100-60 & ; 60 \leq x \leq 100 \\ 0 & ; x<60\end{cases}$

v. Derajat Keanggotaan Nilai Rekomendasi

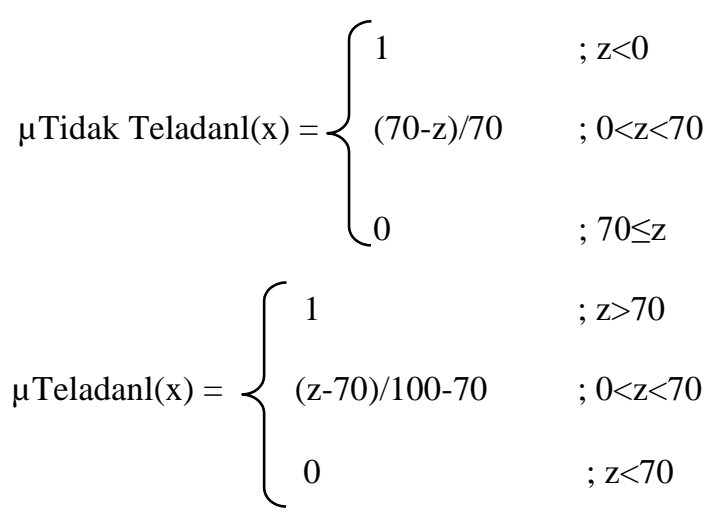




\section{HASIL DAN PEMBAHASAN}

\section{A. Langkah Penyelesaian}

Berikut ini penjelasan mengenai langkah-langkah penyelesaian masalah menggunakan metode fuzzy Tsukamoto dengan sebuah kasus.

Seorang petugas sekolah mangajukan form data nilai siswa bernama Abdul Ajis kepada admin dengan ketentuan sebagai berikut:

Nilai rata-rata rapor $\quad: 73$

Nilai absensi(alpha) $\quad: 4$

Nilai kepribadian $\quad: 78$

Nilai ekstrakurikuler $\quad: 71$

Maka, nilai rapor termasuk kategori rendah dan sedang, nilai absensi termasuk kategori baik dan sedang, nilai kepribadian termasuk kategori cukup baik dan sangat baik sedangkan nilai ekstrakurikuler termasuk kategori cukup baik dan sangat baik. Untuk mendapatkan keputusan yang tepat proses selanjutnya dilakukan metode fuzzy Tsukamoto.

\section{i. Fuzzifikasi}

Langkah pertama yang harus dilakukan adalah mencari keanggotaan masing-masing variable input yang digunakan.

1) Nilai rata-rata rapor

Jika nilai rata-rata rapor $=73$ maka derajat keanggotaan fuzzy pada setiap himpunan adalah:
(1) Himpunan fuzzy rendah $=0$
(2) Himpunan fuzzy sedang $\quad=0,86$
(3) Himpunan fuzzy tinggi $=0,14$

2) Nilai absensi

Jika nilai absensi $=4$ maka derajat keanggotaan fuzzy pada setiap himpunan adalah:

(1) Himpunan fuzzy baik $\quad=0,5$

(2) Himpunan fuzzy sedang $\quad=0,5$

(3) Himpunan fuzzy buruk $=0$

3) Nilai kepribadian

Jika nilai kepribadian $=78$ maka derajat keanggotaan fuzzy pada setiap himpunan adalah:

(1) Himpunan fuzzy tidak baik $=0$

(2) Himpunan fuzzy cukup baik $=0,1$

(3) Himpunan fuzzy sangat baik $=0,9$

4) Nilai ekstrakurikuler

Jika nilai ekstrakurikuler $=71$ maka derajat keanggotaan fuzzy pada setiap himpunan adalah:

(1) Himpunan fuzzy tidak baik $=0$

(2) Himpunan fuzzy cukup baik $=0,45$

(3) Himpunan fuzzy sangat baik $=0,55$

\section{ii. Defuzzifikasi}

Langkah selanjutnya adalah defuzzifikasi output fuzzy. Proses defuzzifikasi pada metode Tsukamoto menggunakan metode weight yaitu dengan membagi jumlah dari hasil $a^{*} \mathrm{z}$ yang ada disetiap rule dengan jumlah dari $a$ yang ada di setiap rule. $(\alpha 1 * z 1)+(\alpha 2 * z 2)+(\alpha 3 * z 3)+\cdots \ldots \ldots \ldots+(\alpha 25 * z 25)+(\alpha 26 * z 26)(\alpha 27 * z 27)$

$$
\mathrm{Z}=\frac{}{\alpha 1+\alpha 2+\alpha 3+\cdots \ldots \ldots . .+\alpha 25+\alpha 26+\alpha 27}
$$

$=80,16667$

Setelah mendapatkan nilai Z langkah selanjutnya adalah mencari keanggotaan masing-masing variabel output lalu membandingkannya.

Jika nilai $\mathrm{Z}=80,16667$ maka derajat keanggotaan fuzzy pada setiap himpunan adalah:

(1) Himpunan fuzzy tidak teladan $=0$

(2) Himpunan fuzzy teladan $\quad=0,43$

Dari hasil perbandingan nilai himpunan output di atas himpunan fuzzy teladan memiliki nilai yang lebih besar dari himpunan fuzzy tidak teladan. Jadi, rekomendasi yang diberikan adalah predikat teladan untuk siswa ini.

\section{B. Tampilan Layar Aplikasi}

Berikut ini merupakan tampilan layar dari form menu utama. Di dalam form menu utama terdiri dari gambar, button data siswa untuk memasukan data siswa, button data nilai untuk memasukkan data nilai siswa, dan button rekomendasi untuk memproses penilaian dan melihat hasil rekomendasi. Rancangan layar form menu utama dapat dilihat pada Gambar 4.

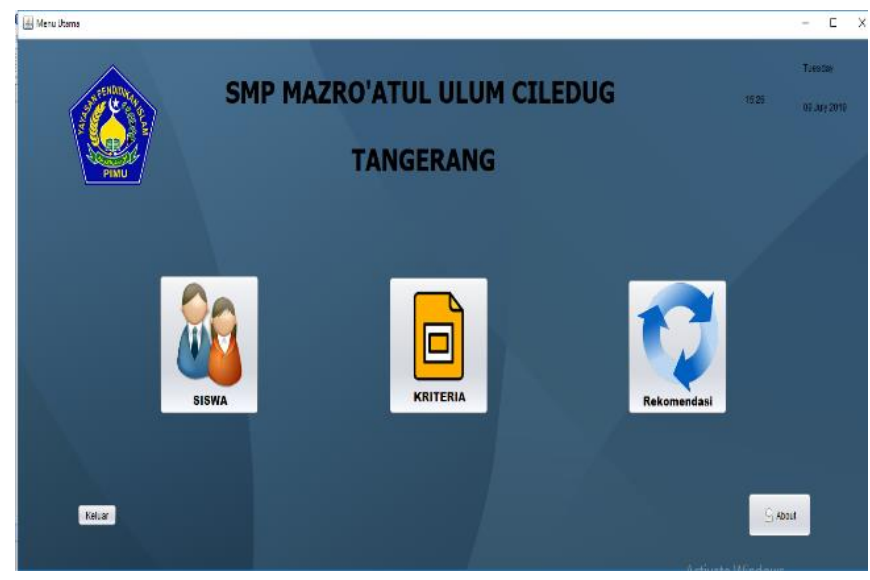

Gambar 4. Tampilan Layar Mепи Utama

Berikut ini adalah tampilan layar dari form data siswa. Di dalam form data siswa berfungsi untuk menyimpan, menghapus, dan mengubah data siswa. User bisa memasukan data siswa berupa NIPD, nama, alamat, kelas, semester, jenis kelamin, dan usia. Terdapat tabel data siswa yang akan menampilkan data dari siswa yang sudah terdaftar. Rancangan layar form data siswa dapat dilihat pada Gambar 5.

Berikutnya adalah tampilan layar dari form data kriteria. Di dalam form data kriteria berfungsi untuk menyimpan, menghapus, dan mengubah data siswa yang sebelumnya, dimana memilih tombol lihat terlebih dahulu agar bisa memanggil data siswa yang data nilainya ingin dimasukkan. User bisa memasukkan data kriteria berupa absensi, nilai ratarata rapor, kepribadian, dan ekstrakurikuler. Terdapat tabel data kriteria yang akan menampilkan data nilai dari siswa 
yang sudah terdaftar. Rancangan layar form data kriteria dapat dilihat pada Gambar 6.

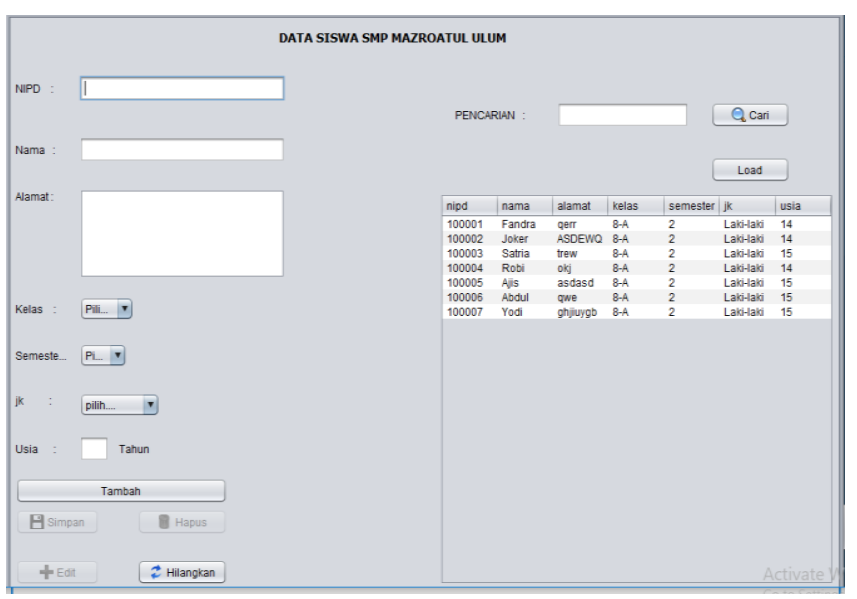

Gambar 5. Tampilan Layar Form Siswa

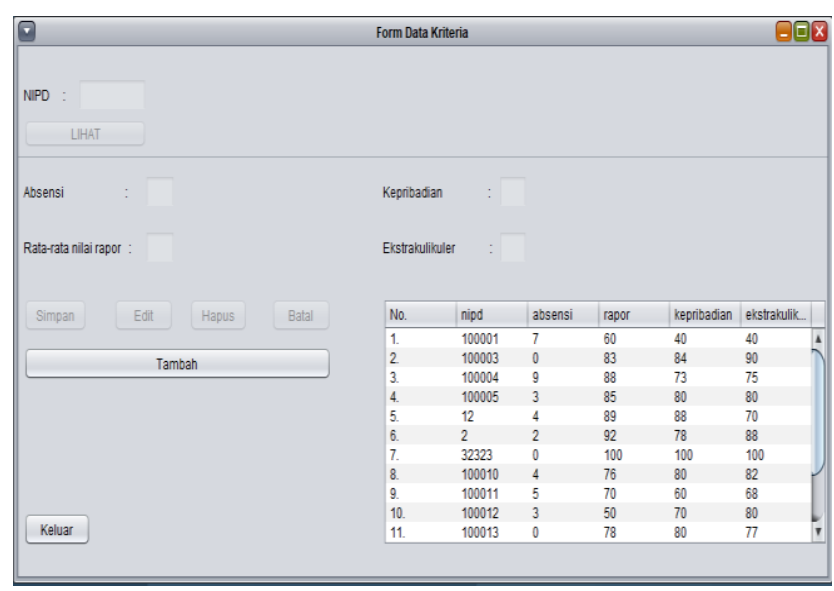

Gambar 6. Tampilan Layar Form Kriteria

Form rekomendasi adalah form yang berfungsi untuk memproses nilai dari siswa yang datanya sudah disimpan dalam form siswa dan kriteria. Untuk selanjutnya user harus memilih tombol cari, jika user menekan tombol cari akan tampil tabel data cari siswa yang akan menampilkan data siswa yang sudah ada nilainya. Selanjutnya user melakukan proses rekomendasi dengan memilih tombol proses nilai dan hasil proses siswa teladan akan langsung tersimpan dalam database. User juga bisa menghapus data dari form rekomendasi dengan memilih data yang ada didalam tabel rekomendasi, selanjutnya tekan tombol hapus untuk menghapus hasil siswa teladan tersebut. Tampilan layar dari form rekomendasi terlihat pada Gambar 7 .

Setelah tombol proses nilai ditekan dan nilai di tiap kriteria sudah muncul, maka akan tampil pesan yang memberitahukan nilai hasil perhitungan berupa probabilitas dan perhitungan fuzzy inference system seperti pada Gambar 8.

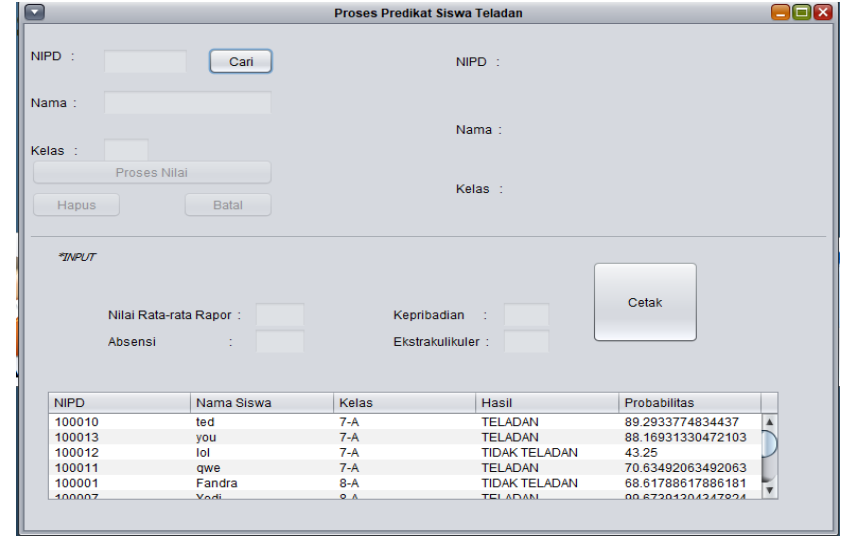

Gambar 7. Tampilan Layar Form Rekomendasi

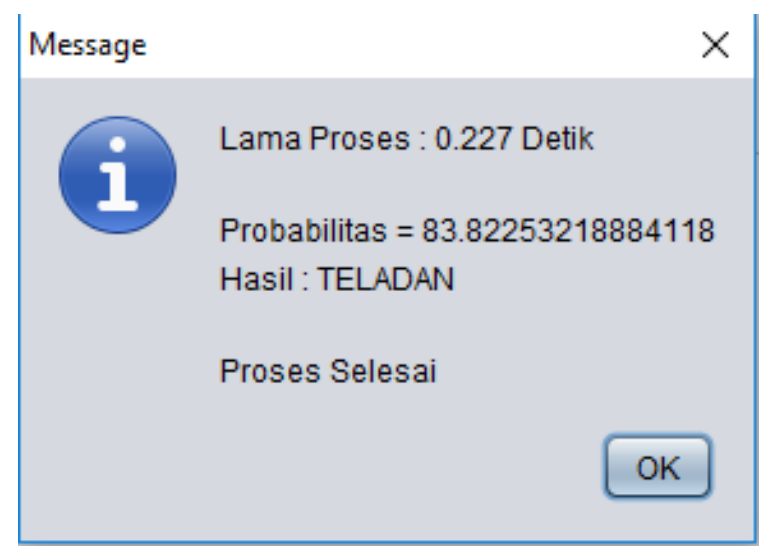

Gambar 8. Pesan Proses Hasil Rekomendasi

User bisa mencetak hasil laporan proses siswa teladan perkelas untuk diserahkan kepada kepala sekolah dan wali kelas untuk disetujui. Yang ditampilkan dalam laporan hasil rekomendasi yaitu NIPD, nama, kelas, hasil, dan probabilitas. Tampilan layar cetak hasil rekomendasi dapat dilihat pada Gambar 9 dibawah ini.

\begin{tabular}{|c|c|c|c|c|}
\hline \multirow[b]{2}{*}{ NIPD } & \multicolumn{4}{|c|}{$\begin{array}{l}\text { Hasil Predikat Siswa Teladan } \\
\text { SMP MAZRO'ATUL ULUM CILEDUG }\end{array}$} \\
\hline & NAMA & KELAS & HASIL & PROBABILITAS \\
\hline 100007 & Yodi & $8 \cdot A$ & TELADAN & 99.67391304347824 \\
\hline 100005 & Ajis & $8-A$ & IELADAN & 75.054587155966328 \\
\hline 100004 & Robi & $8 \cdot \mathrm{A}$ & IELADAN & 70.40909090909009 \\
\hline 100001 & Fandra & 8-A & TIDAR TELADAN & 68.61788617886181 \\
\hline 100002 & Joker & s-A & TIDAR TELADAN & 64.8749999999999999 \\
\hline 100003 & Satria & 8.A & TIDAR TELADAN & 47.849999999999994 \\
\hline
\end{tabular}

Gambar 9. Tampilan Layar Cetak

C. Pengujian Program

Untuk mengetahui apakah sistem ini dapat menentukan rekomendasi siswa teladan, dilakukan uji coba sederhana terhadap sistem. Data pengujian berjumlah 6 data siswa. Hasil pengujian dapat dilihat pada Tabel 3 dan Tabel 4 di bawah ini. 
Tabel 3. Daftar Nilai Tiap Kriteria

\begin{tabular}{cccccccc}
\hline No & NIPD & Nama & $\begin{array}{c}\text { Ke } \\
\text { las }\end{array}$ & C1 & C2 & C3 & C4 \\
\hline 1. & 17187038 & Tsani & $7-B$ & 1 & 77,12 & 75,00 & 80,00 \\
& & B.A.H & & & & & \\
\hline
\end{tabular}

2. 17187042 Rizka A. 7-B $2 \quad 71,50 \quad 75,00 \quad 75,00$

3. 17187061 Riffan P. 7-B $4 \quad 69,00 \quad 60,00 \quad 60,00$

\begin{tabular}{cccccccc}
\hline 4. & 17187037 & $\begin{array}{l}\text { M. } \\
\text { Farhan }\end{array}$ & $7-B$ & 1 & 78,30 & 80,00 & 75,00 \\
\hline 5. & 17187081 & Sarah N. & $7-B$ & 3 & 88,80 & 81,00 & 80,00
\end{tabular}

6. 17187022 Byan I. 7 -B $6 \begin{array}{llll}6 & 81,02 & 80,00 & 90,00\end{array}$

\begin{tabular}{ll}
\hline Keterangan: & \\
C1 $=$ Absensi & C3 $=$ Kepribadian \\
C2 $=$ Rata-rata Rapor & C4 $=$ Ekstrakurikuler
\end{tabular}

Tabel 4. Hasil Pengujian

\begin{tabular}{cclccc}
\hline No & NIPD & Nama & Kelas & $\begin{array}{c}\text { Hasil } \\
\text { Rekomen } \\
\text { dasi }\end{array}$ & $\begin{array}{c}\text { Proba } \\
\text { bilitas }\end{array}$ \\
\hline 1. & 17187038 & $\begin{array}{l}\text { Tsani } \\
\text { B.A.H }\end{array}$ & $7-\mathrm{B}$ & Teladan & 88,38 \\
\hline 2. & 17187037 & $\begin{array}{l}\text { M. } \\
\text { Farhan }\end{array}$ & $7-\mathrm{B}$ & Teladan & 87,97 \\
\hline 3. & 17187081 & $\begin{array}{l}\text { Sarah } \\
\text { N. }\end{array}$ & $7-\mathrm{B}$ & Teladan & 82,02 \\
\hline 4. & 17187042 & $\begin{array}{l}\text { Rizka } \\
\text { A. }\end{array}$ & $7-\mathrm{B}$ & Teladan & 75,10 \\
\hline 5. & 17187061 & $\begin{array}{l}\text { Riffan } \\
\text { P. }\end{array}$ & $7-\mathrm{B}$ & $\begin{array}{l}\text { Tidak } \\
\text { Teladan }\end{array}$ & 68,57 \\
\hline 6. & 17187022 & Byan I. & 7-B & $\begin{array}{l}\text { Tidak } \\
\text { Teladan }\end{array}$ & 67,60 \\
\hline
\end{tabular}

Berdasarkan hasil di atas, menunjukan bahwa menurut perhitungan fuzzy inference system dengan kriteria nilai absensi, nilai rata-rata rapor, nilai kepribadian, dan nilai ekstrakurikuler yang telah dimasukkan, maka siswa dengan hasil probabilitas $>=70,00$ mendapatkan predikat siswa teladan dan nilai tertinggi yang diperoleh adalah 88,38.

\section{KESIMPULAN}

Dari penelitian ini dapat disimpulkan bahwa fuzzy dapat digunakan untuk menentukan predikat siswa teladan berdasarkan data siswa yang dimiliki seperti absensi, nilai ratarata rapor, kepribadian, dan ekstrakurikuler. Hasil dari penentuan siswa teladan tergantung kepada absensi, nilai ratarata rapor, kepribadian, dan ekstrakurikuler serta rules yang dipakai dalam fuzzy. Hasil keputusan digunakan untuk membantu kepala sekolah dan wali kelas dalam penentuan predikat siswa teladan dengan tidak mengandalkan nilai absensi dan nilai rata-rata rapor saja, serta hasil yang didapatkan lebih tepat dan efisien karena terdapat variabelvariabel tertentu. Metode ini juga dapat memberikan rekomendasi yang cepat dan dapat dipercaya. Dan berdasarkan hasil uji coba, menunjukan bahwa menurut perhitungan Fuzzy Tsukamoto dengan kriteria nilai absensi, nilai rata-rata rapor, nilai kepribadian, dan nilai ekstrakurikuler yang telah dimasukan, maka siswa dengan hasil probabilitas $>=70,00$ mendapatkan predikat siswa teladan dan nilai tertinggi yang diperoleh adalah 88,38 .

\section{REFERENSI}

[1] Saifulloh, Winarno, W.W. \& Luthfi, E.T. (2016). Penerapan Fuzzy Logic Dalam Penentuan Kelayakan Pemberian Kredit. Jurnal Ilmiah Multitek Indonesia, Vol. 10(2), pp 1-12.

[2] Anggun, A., Marisa F. \& Wijaya I.D. (2016). Sistem Penunjang Keputusan Pembelian Smartphone Dengan Menggunakan Metode Fuzzy Tsukamoto. Journal of Information Technology and Computer Science (JOINTECS), Vol. 1(1), pp. 27-32.

[3] Erlangga \& Dharmawan, Y.Y. (2018). Penentuan Penerima Kinerja Dosen Award Melalui Metode Tsukamoto Dengan Konsep Logika Fuzzy. Explore Jurnal Sistem Informasi dan Telematika, Vol. 9(2), pp 152-161.

[4] Murti, T., Abdillah, L.A. \& Sobri, M. (2015). Sistem Penunjang Keputusan Kelayakan Pemberian Pinjaman Dengan Metode Fuzzy Tsukamoto. Prosiding Seminar Nasional Inovasi dan Tren (SNIT), pp 252-256.

[5] Parewe, A.M.A.K. \& Mahmudy, W.F., (2016). Seleksi Calon Karyawan Menggunakan Metode Fuzzy Tsukamoto. Prosiding Seminar Nasional Teknologi Informasi dan Komunikasi (SENTIKA) 2016.

[6] Kusumadewi, S. \& Purnomo, H. (2010). Aplikasi Logika Fuzzy Tsukamoto Untuk Pendukung Keputusan. Yogyakarta: Graha Ilmu.

[7] Gautama, M.G. (2010). Penentuan Jurusan di SMAN 8 Surakarta Dengan Fuzzy Inference System (FIS) Mamdani [Skripsi]. Surakarta: Universitas Sebelas Maret. 